Swarthmore College

Works

$5-1-1977$

\title{
Carlo Fontana Had No Part In Bernini's Planning For The Square Of Saint Peter's
}

T. Kaori Kitao

Swarthmore College, tkitao1@swarthmore.edu

Follow this and additional works at: https://works.swarthmore.edu/fac-art

Part of the History of Art, Architecture, and Archaeology Commons

Let us know how access to these works benefits you

\section{Recommended Citation}

T. Kaori Kitao. (1977). "Carlo Fontana Had No Part In Bernini's Planning For The Square Of Saint Peter's". Journal Of The Society Of Architectural Historians. Volume 36, Issue 2. 85-93.

https://works.swarthmore.edu/fac-art/85

This work is brought to you for free by Swarthmore College Libraries' Works. It has been accepted for inclusion in Art \& Art History Faculty Works by an authorized administrator of Works. For more information, please contact myworks@swarthmore.edu. 


\section{SOCIETY OF}

ARCHITECTURAL

HISTORIANS

Carlo Fontana Had No Part in Bernini's Planning for the Square of Saint Peter's Author(s): T. Kaori Kitao

Source: Journal of the Society of Architectural Historians, Vol. 36, No. 2 (May, 1977), pp. 85-93

Published by: University of California Press on behalf of the Society of Architectural Historians

Stable URL: http://www.jstor.org/stable/989105

Accessed: 10-08-2016 14:38 UTC

Your use of the JSTOR archive indicates your acceptance of the Terms \& Conditions of Use, available at

http://about.jstor.org/terms

JSTOR is a not-for-profit service that helps scholars, researchers, and students discover, use, and build upon a wide range of content in a trusted digital archive. We use information technology and tools to increase productivity and facilitate new forms of scholarship. For more information about JSTOR, please contact support@jstor.org.

University of California Press, Society of Architectural Historians are collaborating with JSTOR to digitize, preserve and extend access to Journal of the Society of Architectural Historians 


\title{
Carlo Fontana Had No Part in Bernini's Planning for the Square of Saint Peter's
}

\author{
T. KAORI KITAO Swarthmore College
}

THIS STUDY concerns two of Carlo Fontana's drawings (Figs. I and 2) at Windsor Castle which are related to the plates in his famous volume on Saint Peter's, Templum Vaticanum (Rome, 1694). ${ }^{1}$ They both describe Bernini's colonnades; and, in their concern with measurements, they might well be taken as preliminary sketches for the design of the Square of Saint Peter's. But they are in fact sketches only for the book and not for the colonnades. Moreover, they demonstrate that Carlo Fontana's participation in Bernini's planning of the Square, still widely assumed, is-to say the least-most improbable.

It is generally believed that Carlo Fontana was a pupil of Bernini in the 1660s-just when the latter's colonnades were rising. One might naturally assume, therefore, that in drawing up his plates, Fontana had a firsthand knowledge of his teacher's design. ${ }^{2}$ But he did not. As I have shown elsewhere, Fontana was consistently inaccurate in his published plans with regard to the geometry of the oval piazza and very unsure about its dimensions; and he did not know the existence of what would have been a valuable source of information for him-the Vatican Plan, the large and very accurate

I. Windsor Castle, Royal Library, Inv. 9936 and 9942, respectively. James S. Ackerman very kindly first called my attention to these drawings. A. Braham and $\mathrm{H}$. Hager, The Drawings by Carlo Fontana in the Royal Library in Windsor Castle, announced for publication since 1968 and long awaited, regrettably has not appeared yet.

2. Fontana's plans of the Square of Saint Peter's from his Templum Vaticanum have frequently been and still are occasionally referred to as though they accurately represented Bernini's design: e.g., M. von Boehn, Lorenzo Bernini (Leipzig, I9I2), fig. 43, and more recently, Encyclopedia of World Art (New York, 1959-1968), II, fig. 475, s.v. Bernini (by P. Portoghesi), and M. and M. Fagiolo dell'Arco, Bernini (Rome, 1967), fig. 75. Fontana's plans, together with Letarouilly's derived from them, have been accepted as reliable documents in part because they constitute the only readily reproducible plans; but it is also because it has been said that Fontana apprenticed in Bernini's workshop. Angela Guidoni goes so far as to interpret the distortion in Fontana's plan as Bernini's own and speaks of "un momento di maggiore disponibilità di Bernini all'obliquo [i.e., Caramuelian oblique architecture]" in her recent, fascinating study, "Il Colonnato di Piazza S. Pietro: Dall'architettura obliqua di Caramuel al 'classicismo' berniniano," Palladio, xxIII (I973), 8I-I2O. working drawing produced in Bernini's workshop in the winter of $1658 / 59$ (Fig. 3). ${ }^{3}$

The first of our Windsor drawings, then, confirms this fact. The colonnade describes a simple circular arc, as Fontana showed on all his published plans (Figs. 4 and 5), not

3. T. K. Kitao, Circle and Oval in the Square of Saint Peter's: Bernini's Art of Planning (New York, 1974), pp. 38-42, and fns. 6, 66, and 153.

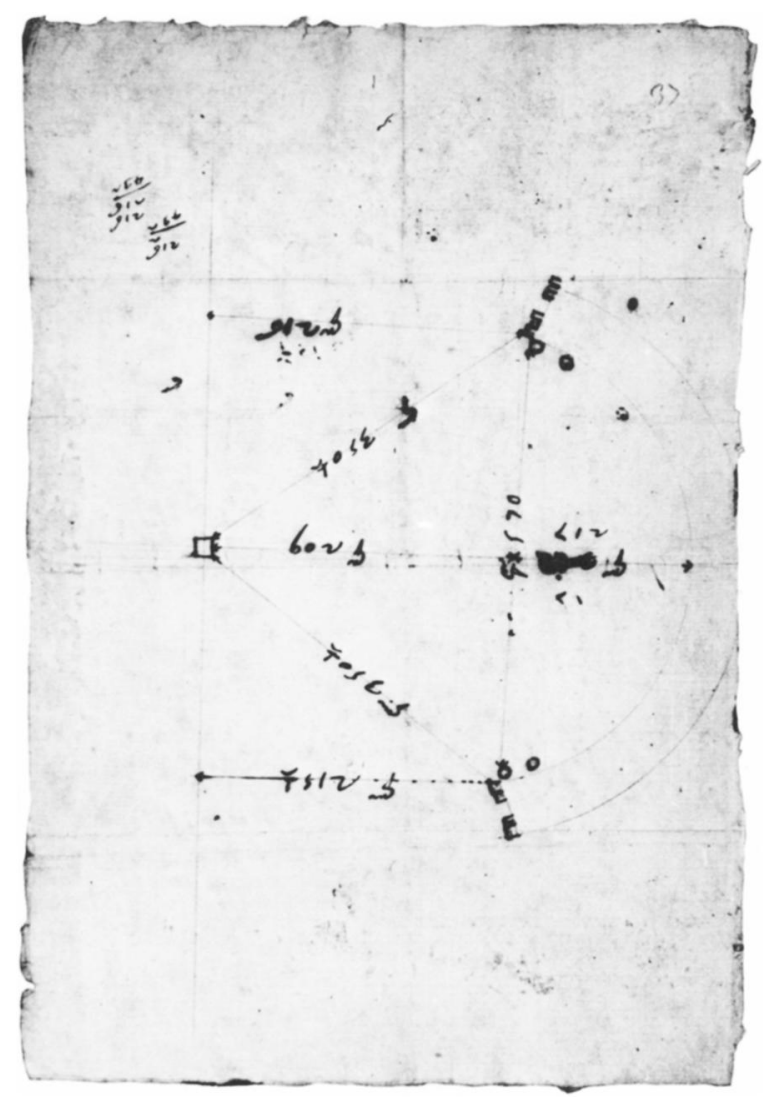

Fig. I. Carlo Fontana, Survey sketch, Piazza Obliqua (Royal Library, Windsor Castle, reproduced by gracious permission of H.M. The Queen). 
the composite curve on which it was actually laid out. ${ }^{4}$ Moreover, the drawing shows that he had to take his own measurements. It is an outline plan of one of the colonnades together with the obelisk, and there are some inscribed di-

4. Templum Vaticanum, pp. I8I and 185 , respectively; see also the plans on pp. 205, 21I, 213, 22I, and 23I, among others. See also Kitao, Circle and Oval, fn. 162 .

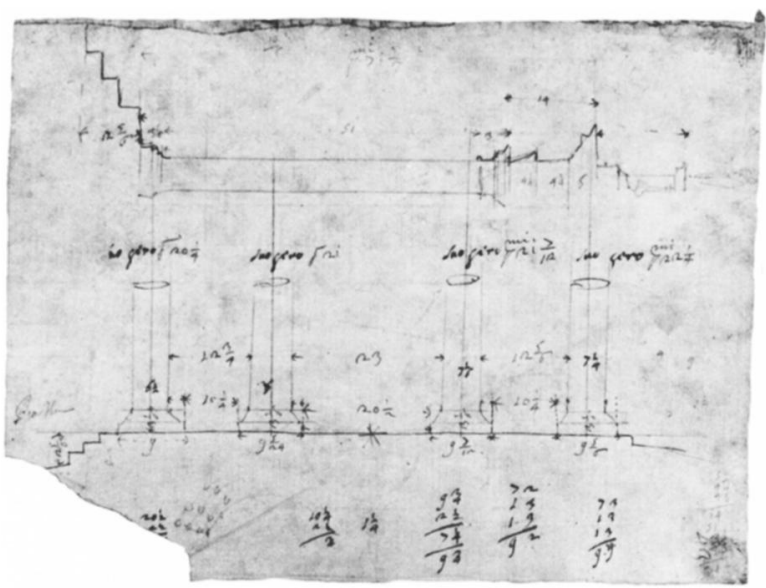

Fig. 2. Carlo Fontana, Survey sketch, Bernini's Colonnade (Royal Library, Windsor Castle, reproduced by gracious permission of H.M. The Queen).

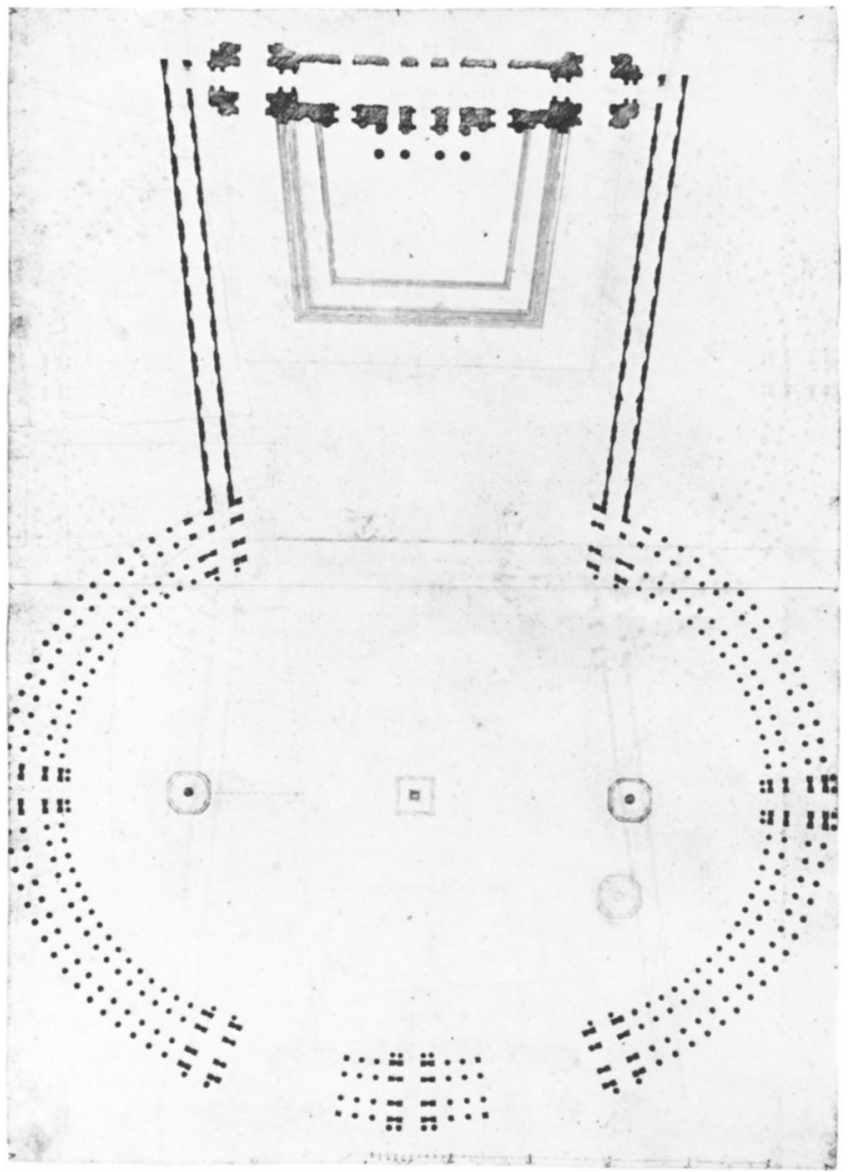

Fig. 3. The Square of Saint Peter's, the "Vatican Plan" (Vatican Library). mensions. It is immediately obvious that the plan is a survey sketch; it represents a process of recording measurements of a structure that already stands rather than a process of working out a new layout.

Three features of this drawing are noteworthy in this regard. First, the plan is diagrammatic. The colonnade is drawn more or less to scale, but the obelisk is too far away from it; and the two ends of the colonnade are incorrectly represented, both identically shaped and provided with four pilasters rather than two columns and two pilasters as they should be (Fig. 3). Second, the recorded measurements do not include the radius of the colonnade though this is crucial for laying it out. Finally, measurements were generally taken of clear distances between "corners" (i.e., rather than on centers) except when this was either impossible or impractical. One also observes that the drawing was executed in two installments. Architectural elements and dimension lines were drawn first using a square and compasses, and the rest was added later freehand-the dimensions in palmi (from the measurements taken undoubtedly in situ) together with the arrowheads and certain details that served as controls for sighting and measuring. ${ }^{5}$ We can be certain, therefore, that the drawing was made in preparation for the Templum Vaticanum, not in the course of the design of the project it represents.

The dimensions inscribed on the drawing are generally accurate, but there are some discrepancies between them and those recorded in the book. For example, the dimensions in the sketch add up to 430 or 432 palmi for the opening between the two colonnades, which is given as 427 in the text of the book. One speculates that some of the measurements were retaken and modified before publication. ${ }^{6}$ In any case, it is evident that Fontana never worked on the Vatican Plan and hardly knew it. This, as we know, was the definitive plan so far as the colonnades were concerned; construction started soon after it was made. The Bonacina engraving (Fig. 6) was also ready for circulation about the same time, and it is this engraving which I proposed previously as the most likely source of information for Fontana,

5. The obelisk, the pilasters and columns, and the arrowheads were traced over with pen and ink for the second time when the figures were inscribed.

6. That this sketch was a study for the plan on p. I8I of Fontana's book (our Fig. 4) is corroborated by the erroneous four pilasters, repeated in the published version, which terminate the colonnade; cf. fn. I4, below. Fontana's figure for the opening between the two colonnades is in Templum Vaticanum, p. 183 . The sketch gives 215 and 216 palmi for the distance from a corner of the colonnade to the centerline of the piazza. In two calculations 216 is first multiplied by 2 and, as though for verification, 216 is then added to 216 , yielding 432 . The dimensions entered on the major axis of the piazza read 217 and 209; the sum, 426, makes sense only if the measurement was from the obelisk to the projecting columns of the central cross-passage rather than the first course of columns as the arrow indicates. Other dimensions in the sketch were not used in the book. 


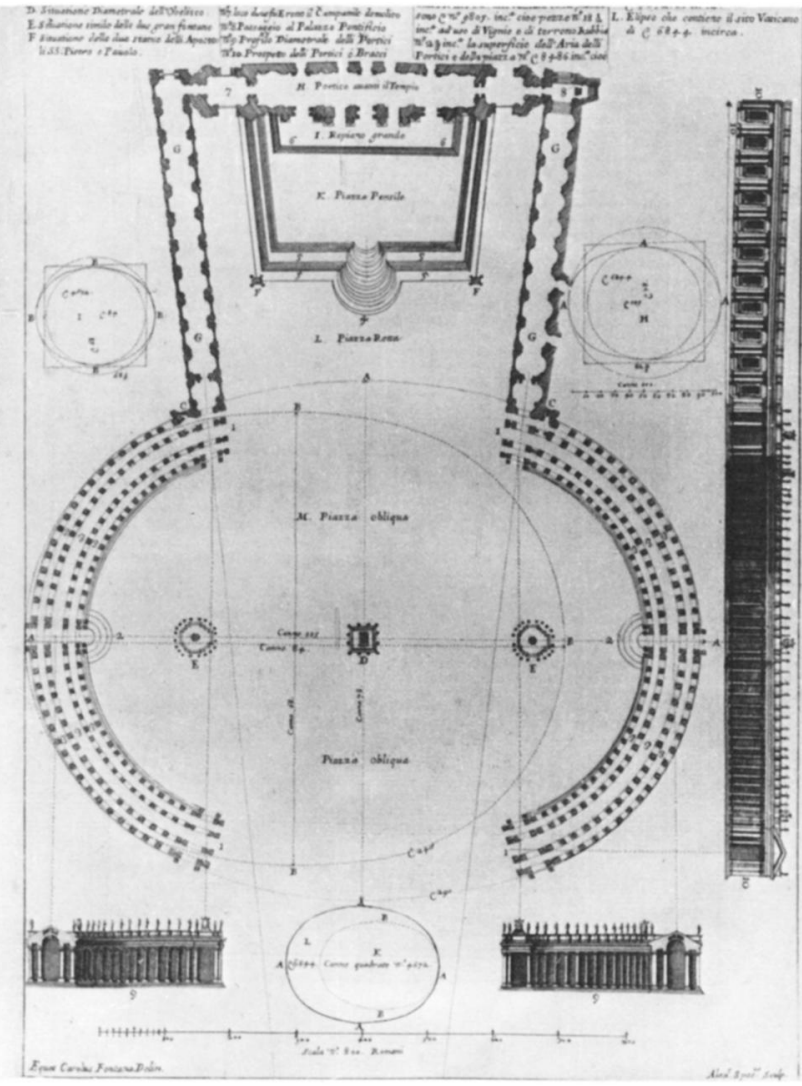

Fig. 4. Carlo Fontana, The Square of Saint Peter's, plan, Templum Vaticanum, p. I8I.

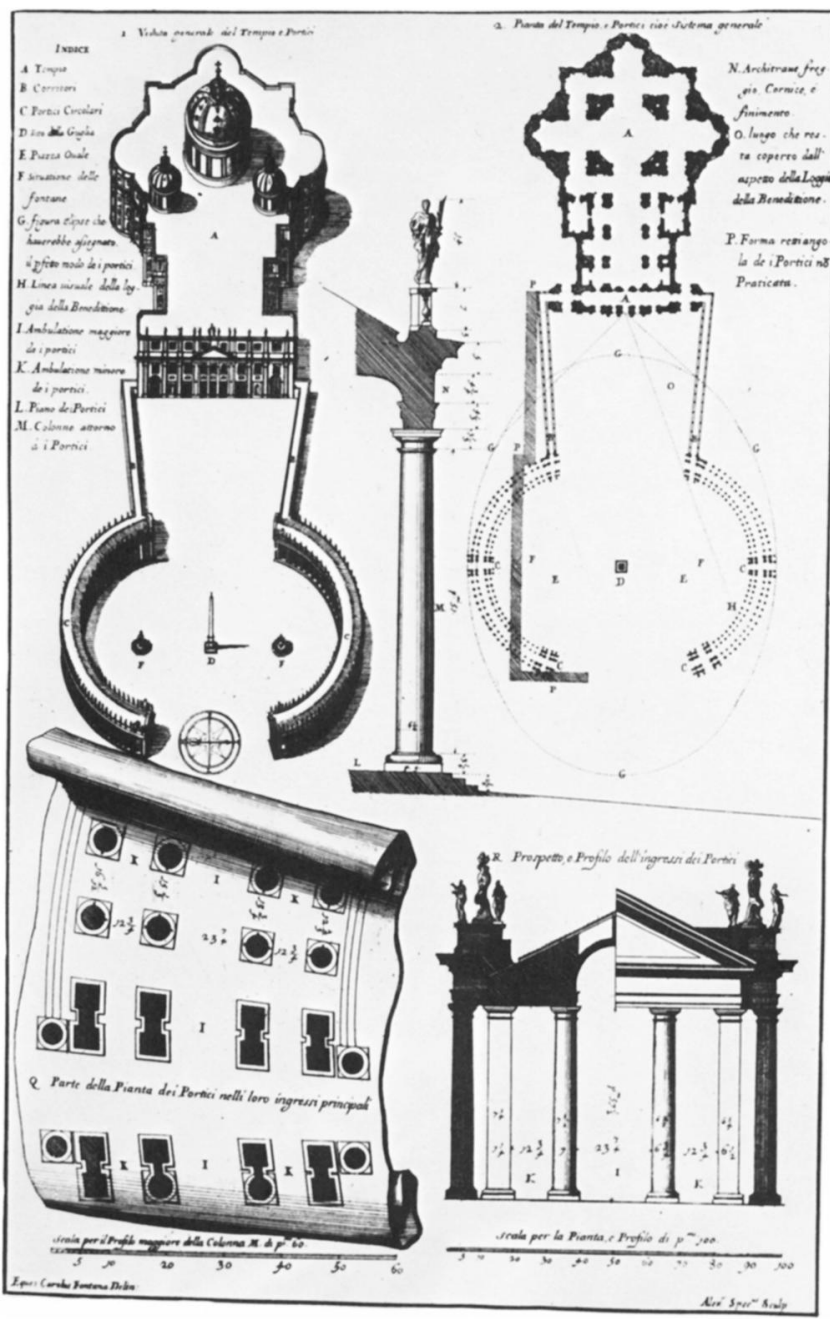

Fig. 5. Carlo Fontana, Bernini's Colonnades, engraving, Templum Vaticanum, p. 185 .
Fig. 6. G. B. Bonacina, Engraving, Bernini's Colonnades (Vatican Library).

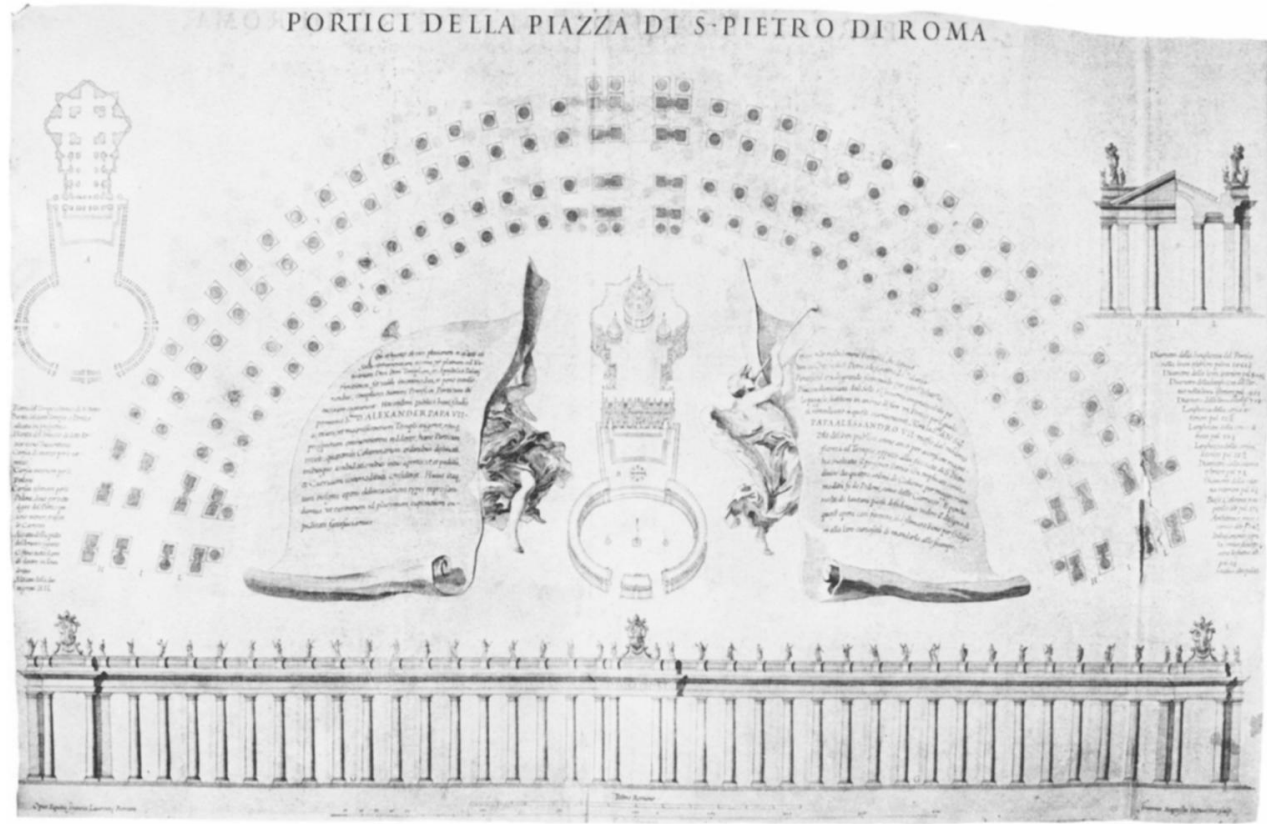


since on it the colonnade also traces a single circular arc. ${ }^{7}$

Our second Windsor drawing (Fig. 2) changes my view on this point. It further confirms Fontana's conspicuous absence from the crew assisting Bernini in his project for the Piazza Obliqua and, in addition, strongly suggests that he may not even have seen the Bonacina engraving. This drawing is also a survey sketch made for recording measurements, and it, too, was executed in two installments. It contains two items, single columns with entablature in profile, and in another orientation, a row of four columns of progressively augmented diameter. The columns are all drawn somewhat off scale but with inscribed dimensions which, significantly, include the circumferences of the four as well as their diameters.

This drawing is readily recognized, unlike the other, as a sketch for a specific plate (one on p. 185 ) in the Templum Vaticanum. The plate gives us a section-elevation of the colonnade (Fig. 5), in which column diameters-but not circumferences-are entered. It is apparent that in the sketch the diameters were calculated from the circumferences rather than vice versa. Circumferences are naturally more easily measured on the site than diameters, for which calipers might ordinarily be used-but these columns are over five feet across. Circumferences, on the other hand, are of little use to draftsmen and masons in their work of design, layout, and construction, if diameters are given. It is also noteworthy that the circumferences in the sketch are more precisely graded than diameters. ${ }^{8}$ It is evident that Fontana did not have on hand the column dimensions he needed for his book and had to obtain them on his own-directly from the monument.

In the legend on his engraving G. B. Bonacina provided the diameters of the smallest and largest columns as well as certain dimensions in elevation. If Fontana knew the engraving, he either missed the measurements or else ignored them (Fig. 7). Bonacina could have erred, of course; that would have been a good reason for Fontana to ignore his figures. But this is unlikely, for there is other evidence to consider.

Fontana called the base of Bernini's column Tuscan in the text of his book and illustrated it consistently as such (Fig. 7) even though, as Thieme recently observed, it is actually Roman Doric (Fig. 8 ; note the molding above the torus). ${ }^{9}$

7. Kitao, Circle and Oval, p. 42. On the dating of the Bonacina engraving and the Vatican Plan, see ibid., fns. 65, IIO, II2, and 155.

8. See the tabulation below. The accretion from the first column to the second is $3 / 4$ palmo, that from the third to the fourth $1 / 12$ less (i.e., $2 / 3$ palmo), for the circumferences; the accretion in the diameters is correspondingly $1 / 2$ and $1 / 12$ palmo. In the published plate, these are more accurately and consistently $1 / 4$ palmo each.

9. T. Thieme, "La geometria di Piazza San Pietro," Palladio, XXIII (I973),

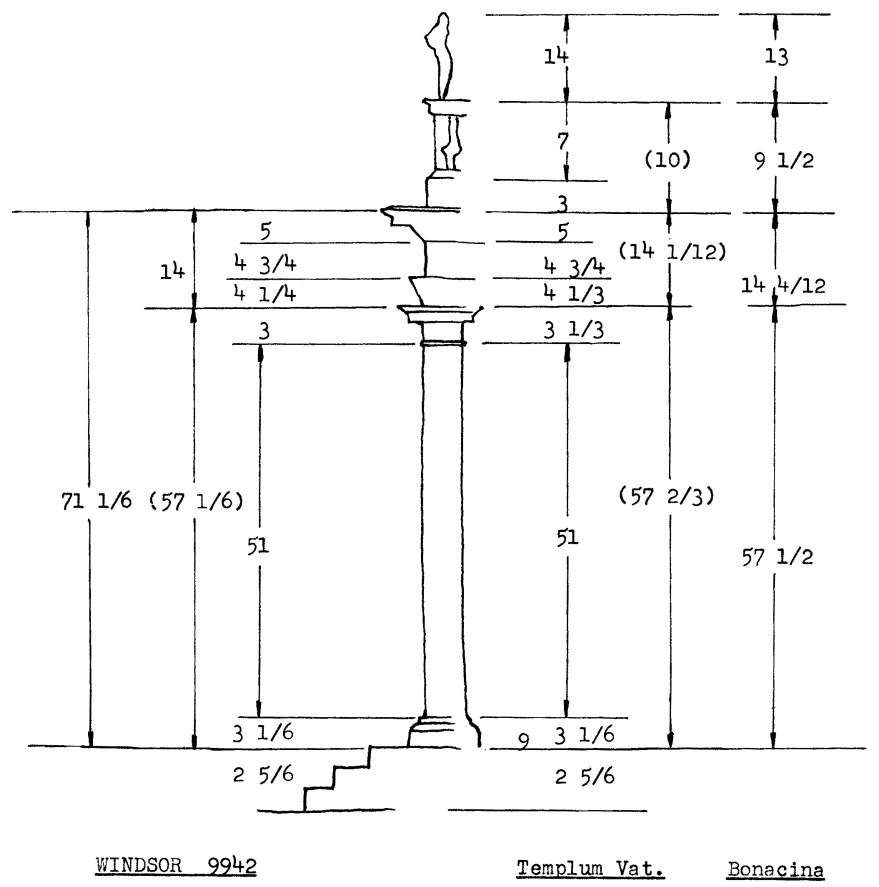

Fig. 7. Bernini's Colonnade, comparative dimensions in elevation (diagram: author).

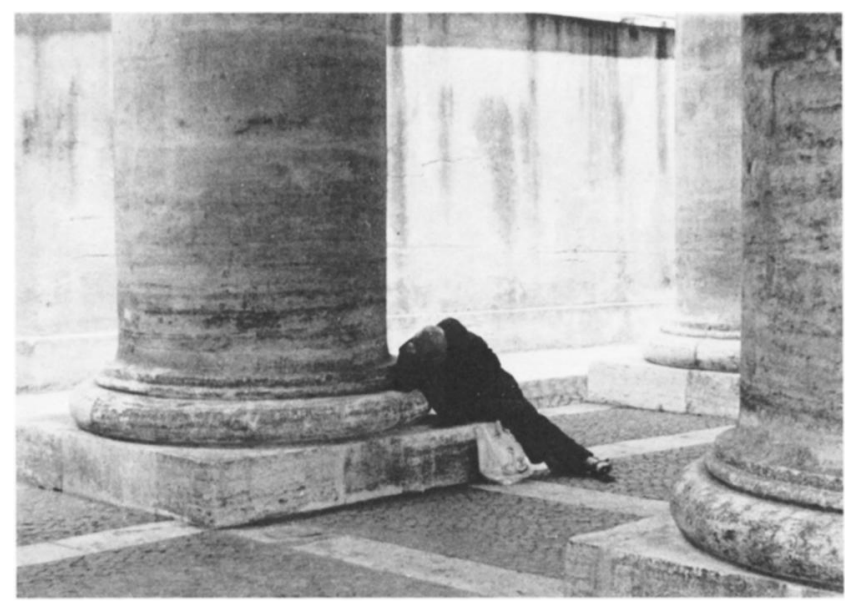

Fig. 8. Bernini's Colonnade, Roman Doric base (photo: author).

His section-elevation, seemingly an accurate mirror image of Bonacina's version (Fig. 9), does not repeat the latter's correct Roman Doric base-a discrepancy that weakens the case for the possible derivation of one from the other. ${ }^{10} \mathrm{In}$

I20-I44, esp. p. I35; in Fontana's own words, "sono di tre qualità d'ordini gli ornamenti de' predetti portici, cioè la Base d'ordine Toscano, il fuso delle Colonne, con suo Architraue, Fregio e Cornice, Ionico, col Capitello Dorico" (Templum Vaticanum, p. I87). In discussing measurements and geometry, Thieme is not as precise as he could have been.

Io. The section-elevation in the engraving agrees completely with that in the preparatory drawing (our Fig. Io; British Museum, Payne Knight Oo $3^{-}$ 5). The Roman Doric base was already a feature in Bernini's "Arcade Plan" of the spring of 1657 , though the columns were probably Ionic in proportion; see Kitao, Circle and Oval, pp. I5-16, fn. 53, and figs. 17 and 19. 
the Windsor drawing the base is, as expected, of Tuscan Order, linking the sketch directly with the book. On the other hand, since this is a measurement drawing with measurements evidently taken in situ, Fontana's failure (or refusal) to correct the error is bewildering. It is as though, having verbally described the base as Tuscan, he was so convinced of the proposition that he did not even bother to look at the very work of which measurements were being taken. ${ }^{11}$

The carelessness (if that is what it is) is contrary to the meticulousness with which Fontana handles numerals. As in the case of the first Windsor drawing, the figures in the sketch were subsequently modified, presumably on the basis of additional data, for the final entry in the book. The changes were not always for the more precise, but, as the tabulation below shows, they were sometimes extremely minute. ${ }^{12}$ The exceptional fastidiousness Fontana shows here is matched by his precision in describing the colonnades. ${ }^{13}$ But he was incredibly careless in his visual documentations. In those plans for the Templum Vaticanum which included Bernini's colonnades, he made and tolerated some glaring errors and inconsistencies. The colonnade may end with four pilasters, as we have seen (Fig. 4), but not always. The cross-passage at the eastern termination may have four framing columns (incorrectly) or two (correctly); the cross-passage at the midpoint of the colonnade may be framed on the side facing the town by four columns (Fig. 5), two (Fig. 4), or correctly none. ${ }^{14}$

II. One could, of course, argue in reverse and say that because this is only a measurement drawing, Fontana had no reason to be particular about irrelevant details; and he could have delegated his assistant to go to the site for measurements. But the point is that he carried the error into the book.

I2. Fontana made some inexplicable changes. For example, the ratio of the width of the side aisle to that of the wider middle aisle is $\mathrm{I} .8$ in the sketch, which agrees with the result of my survey; in Fontana's book, it is I.86. There are inconsistencies in the numerical figures in the sketch, too. The difference between the smallest column diameter and the width of the base for it is $21 / 2$ palmi. As the inscribed calculations show, this value was used to compute intercolumniations from the clear distances between the bases: IO $1 / 4+2 \frac{1}{2}$ and $20^{1 /} / 2+21 / 2$; but it does not match the values obtained from the inscribed measurements for the second and third column diameters and their respective bases, viz. $2^{5 / 24}$ and $2^{5 / 12}$. Another inscribed calculation, $9^{3 / 4}-21 / 2=71 / 4$, obviously refers to the largest column, but the base of that column is inscribed $95 / 6$ instead.

13. Kitao, Circle and Oval, fn. 75 ; also pp. $74^{-75}$, where Fontana's phrase "true ellipse" is discussed.

I4. The plan on p. ${ }^{213}$, for example, shows no framing columns on the outside of the middle cross-passage. It must be noted, too, that the northern colonnade terminates here with two pilasters and two columns but the southern counterpart terminates with four pilasters! This plan is reproduced in H. Hager, "Progetti del tardo barocco romano per il terzo braccio del colonnato della Piazza S. Pietro," Commentari, xIx (I968), fig. 6. The rhombic distortions of column bases that characterize the eastern terminal of the colonnade in the Bonacina engraving appear in some of Fontana's plans (our Fig. 4) but not in others (our Fig. 5); in the latter, moreover, the right and the left do not even match in size.

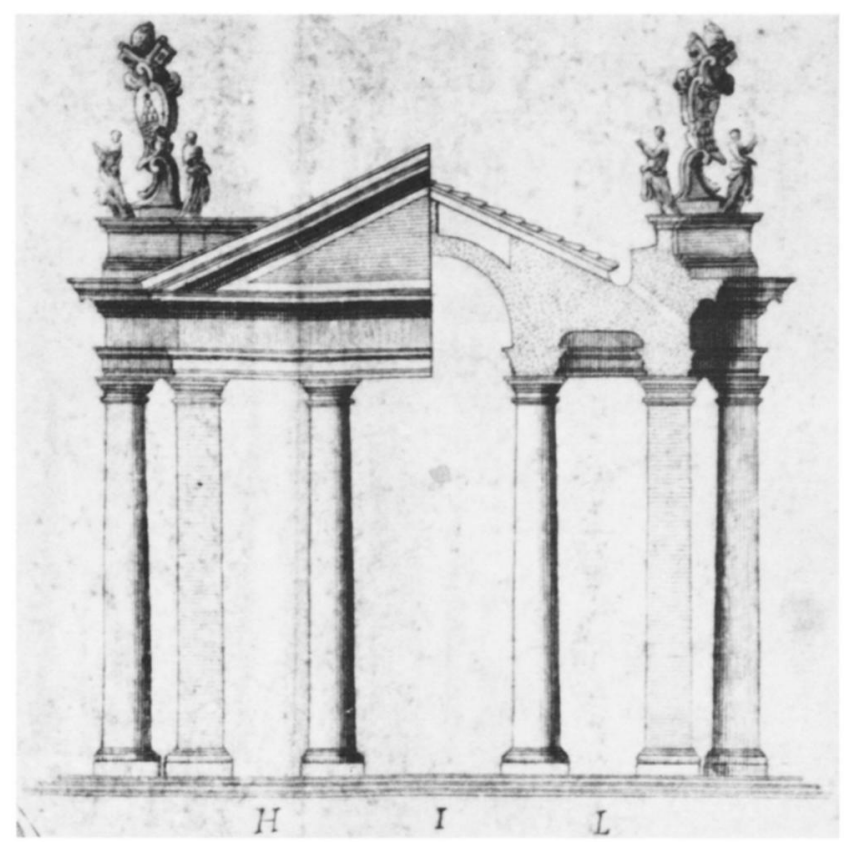

Fig. 9. G. B. Bonacina, Colonnade Section-Elevation, detail of Fig. 6.

How does all this carelessness support the argument that Fontana never looked at the engraving? It may seem rather to challenge it ; Fontana was generally careless, so his failure to repeat Bonacina's Roman Doric base does not necessarily prove that he did not know the engraving. If he failed to see Bernini's actual base, this only makes him fully capable as well of an oversight with regard to Bonacina's details. Given this penchant of his, one could possibly hypothesize that Fontana did after all resort to the Bonacina engraving butas with the monument itself-details escaped him. One must then say with regard to Bonacina's dimensions that Fontana saw them but, fastidious with numerals, did not accept them without checking them out on the site himself. The hypothesis that Fontana did know the Bonacina engraving but ignored the details thus seems to hold up almost as well as the assumption that he was never exposed to it. Almost but not quite, for there is yet more evidence.

One wonders how Fontana, had he known the engraving, could have been so insensitive to, or forgetful of, still another crucial detail-the projecting double columns that frame the outside façade of the central cross-passage. The four framing columns appear in the Bonacina engraving (Fig. 6), but not in the preparatory drawing (Fig. IO). Never brought to execution, they were convincingly explained by Wittkower as a part of the aborted project of constructing a new pilgrims' road. The road was to run northward on the extended axis of the major diameter of the oval piazza, and the projecting double columns would mark the vista for those 


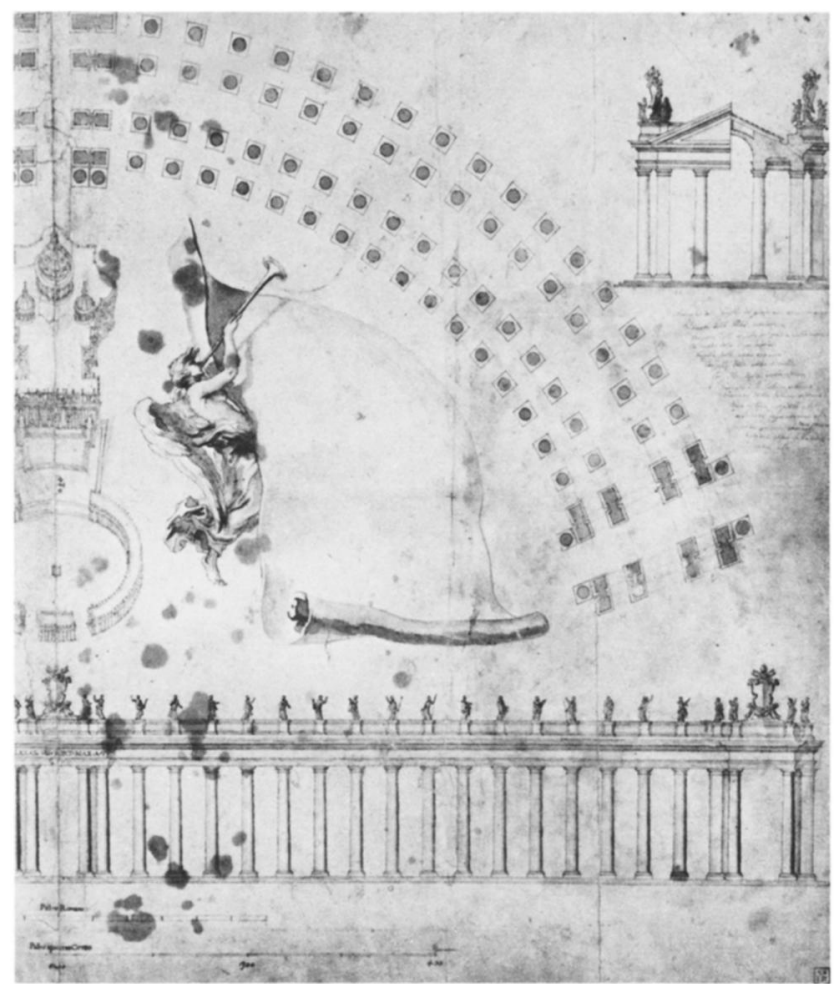

Fig. Io. Preparatory drawing for Bonacina engraving, left half (British Museum).

approaching the piazza from this direction. ${ }^{15}$ The project, requiring a vast urban reconstruction was obviously overambitious and was dropped by $\mathrm{I} 66 \mathrm{I}$ at the latest, the year of the completion of the northern colonnade. ${ }^{16}$

In addition to Bernini's own sketches, there exists in the Vatican an enormous working drawing which concerns this project (Fig. II). According to Wittkower, it was "probably made by Carlo Fontana, Bernini's assistant at that time." 17 Since the drawing incorporates a plan from a copy of the Bonacina engraving (cut out and pasted at the bottom), it must be dated 1659 or later. That it shows no more than an earliest phase of the project-a schematic indication by a single line where the road would be positioned-makes 1659 the most likely date.

If the pilgrims' road plan can be securely attributed to

I 5. R. Wittkower, "A Counter-project to Bernini's 'Piazza di San Pietro,", Journal of the Warburg and Courtauld Institutes, III (1939-1940), 88-106, esp. pp. 94 and 99; see also Kitao, Circle and Oval, fns. IIO, II2, and I54, and pp. $46^{-} 49$.

16. This was commemorated by a medal (Fig. I4); see Kitao, Circle and Oval, p. 49. The framing columns were never built but the medal shows them anachronistically following the design on the Bonacina engraving. It is more likely that the project was dropped soon after the start of the construction, since columns began to rise starting with the central cross-passage; see Kitao, fns. 65 and 70.

I7. Bibl. Vat., no inventory number, about seven feet long; Wittkower, “A Counter-project," p. 94, fn. 3.

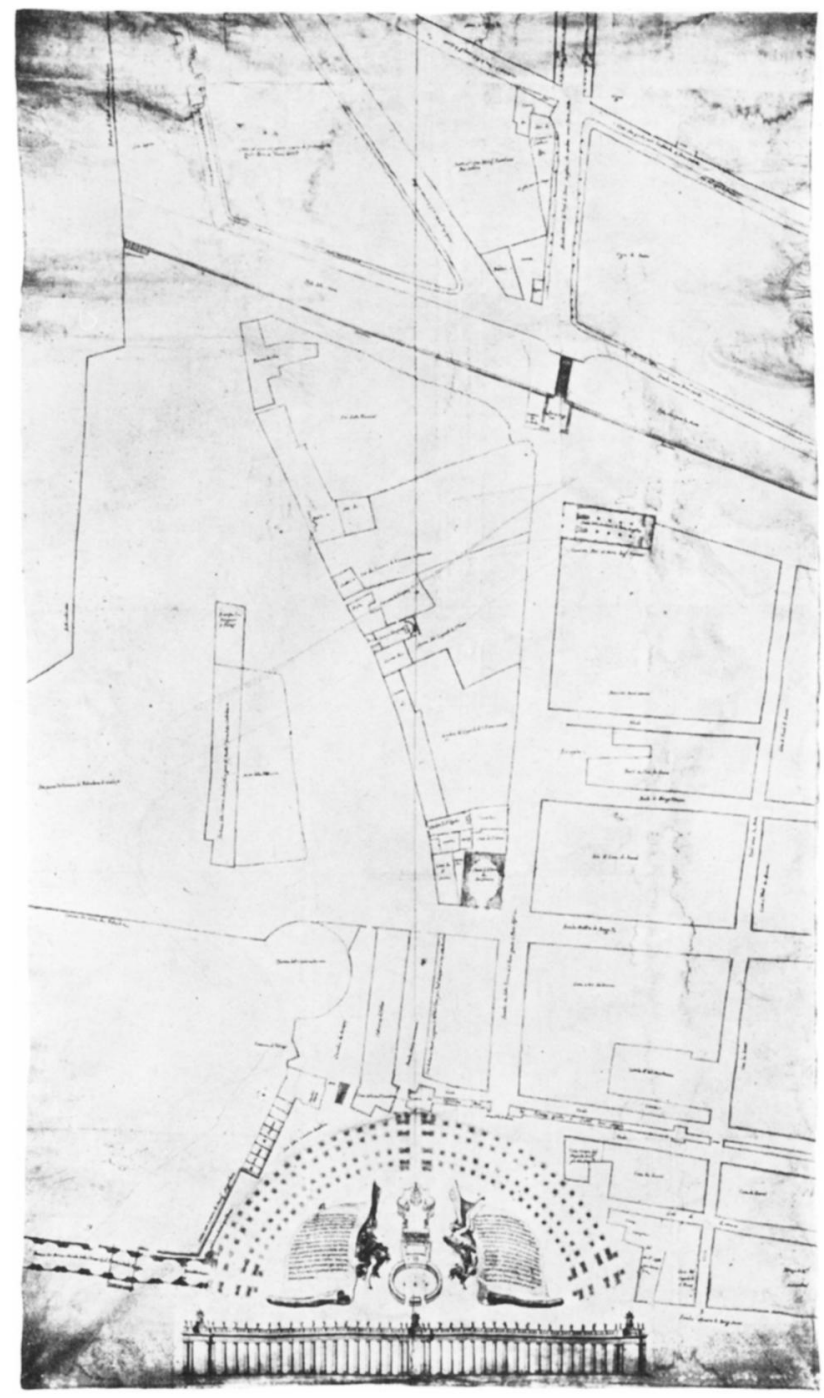

Fig. II. Pilgrims' Road Project, Bernini workshop (Vatican Library, from Art Bulletin, XLVII, fig. I2, between pp. 214 and 215).

Fontana, we cannot of course say that he did not know the Bonacina engraving. But, then, we must conclude that he was remarkably irresponsible in his failure-whether by negligence or by refusal-to achieve accuracy in his monumental monograph. For he could not have been uncertain, as he was, of the crucial four projecting columns (even though they did not get executed), inasmuch as this detail would not have been but noticed, for its implication, apart from other details he could easily have misrepresented from carelessness and did. The fact is, however, that he was, as we have seen, as indifferent to this particular detail as to the others he misrepresented. We are therefore persuaded to believe that Carlo Fontana neither had anything to do with the pilgrims' road project in 1659 nor was acquainted with the Bonacina engraving at that time. We can still say that if Fontana could not have known the engraving at the time it 
Fig. I2. Bernini's Colonnade, elevation, attributed to Carlo

Fontana (Vatican Library).

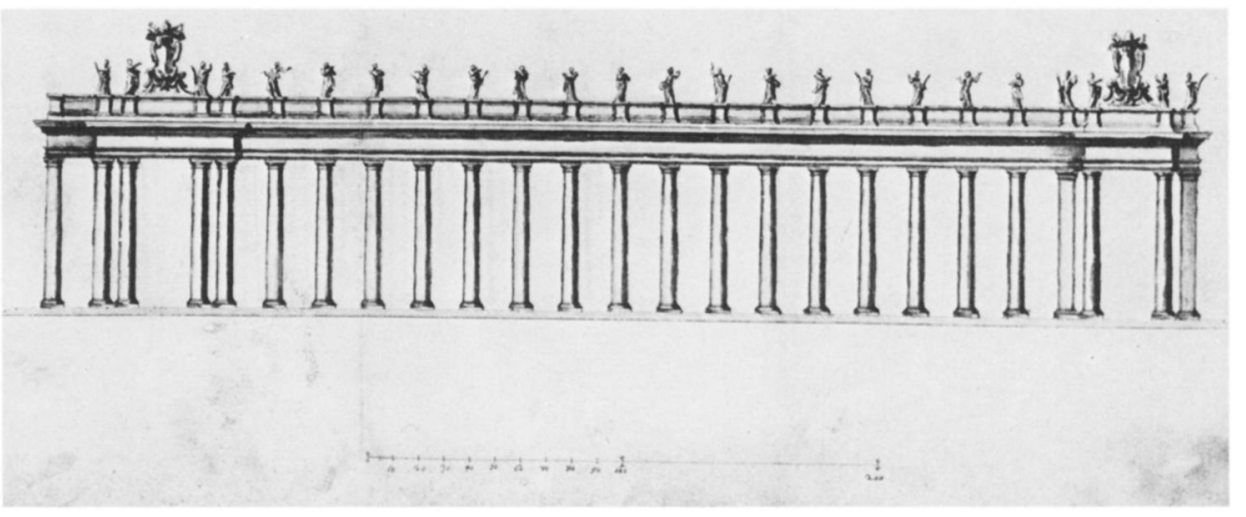

first appeared, i.e., in 1659 , he might well have gained access to a copy when he began compiling materials for his book many years later. We cannot exclude this possibility; but, in that case, he still used the engraving only perfunctorily for general information and paid little attention to details.

This evidence, together with our earlier conclusion that Fontana could not have taken part in the design of Bernini's colonnades before 1659 since he had not known the definitive Vatican Plan, thus severely undermines his presumed participation in the planning of the Square of Saint Peter's during his apprenticeship in his teacher's workshop. It is indeed very likely that he had no part in it.

It is certainly noteworthy that not one single signed drawing by Carlo Fontana is known in connection with the Piazza Obliqua. Perhaps for this reason Coudenhove-Erthal denied Fontana's assistantship in Bernini's piazza project, and Ugo Donati followed suit. ${ }^{18}$ It was none other than Rudolf Wittkower who first discussed the young architect's contribution to the design of the colonnades in his study of I93I, but his evidence was surprisingly tenuous. It consisted of a single drawing with two elevations of the colonnade (Figs. I2 and 13), in which Fontana's hand was thought to be recognized. ${ }^{19}$

Wittkower dated the drawing slightly earlier than the Bonacina engraving (which he then incorrectly believed to have represented the definitive design) by internal evidence - paired pilasters are separate here rather than joined by a

I8. E. Coudenhove-Erthal, Carlo Fontana und die Architektur des römischen Spätbarocks (Vienna, I930), p. 20, where the author has only the following to say: "Von sonstigen grösseren Bauten Berninis kämen für diese Zeit noch die Kolonnaden des Petersplatzes in Betracht; hier aber Fontana offenbar nicht mitgewirkt. Er hätte es gewiss nicht verschwiegen, als er später seinen grandiosen Erweiterungsplan der Berninischen Anlage veröffentlichte." U. Donati, Artisti ticinesi a Roma (Bellinzona, I942), pp. 264-265: “. . . sembra che non intervenisse nell'impresa architettonica più grandiosa e meravigliosa del Bernini, la costruzione del colonnato di piazza S. Pietro."

I9. H. Brauer and R. Wittkower, Die Zeichnungen des Gianlorenzo Bernini (Berlin, I93I), pp. 82 and 87. The drawing is Bibl. Vat., Chig. P VII 9, fol. 23.

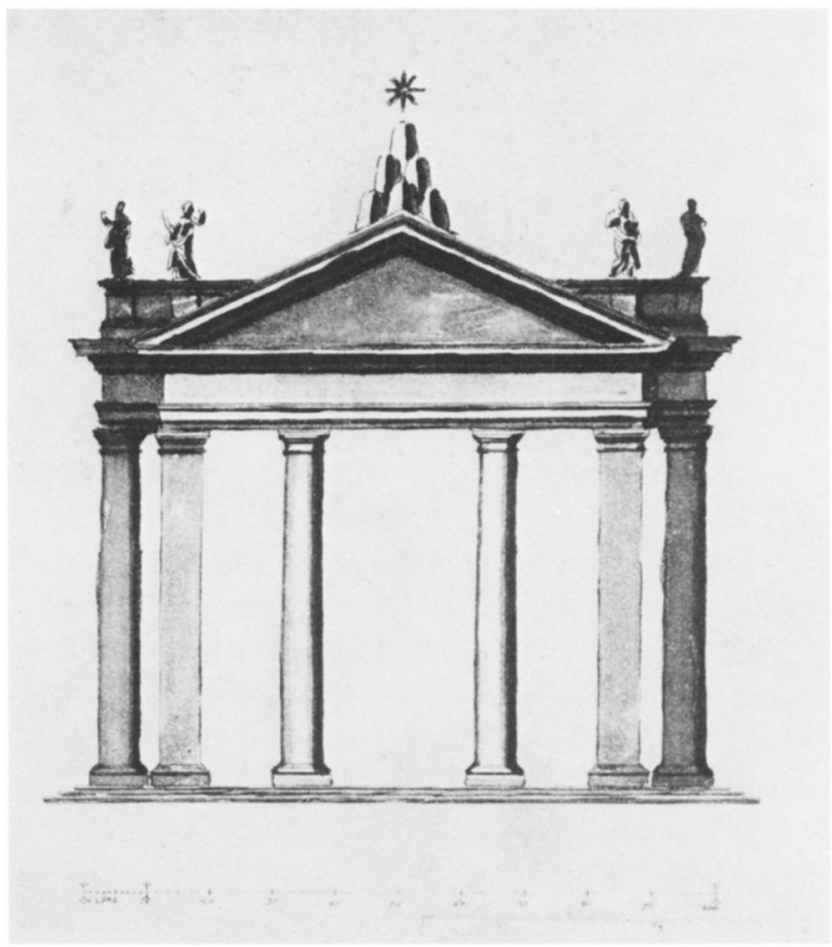

Fig. I3. Colonnade Temple Front, variant design, attributed to Carlo Fontana (Vatican Library).

web of wall into twin-pilasters. And he characterized the gable surmounted by the Chigi Monti as "ein selbständiger Versuch des jugendlichen Carlo Fontana," relating it to his contemporary design for the façade of Santa Maria del Popolo. ${ }^{20}$

But the dating is open to question. The connecting webs of the twin-pilasters could well have been omitted by oversight or by intention. They are surely an unusual feature. But they are a subordinate feature, too, that could easily

20. Brauer and Wittkower, Die Zeichnungen, p. 82, fn. 5 ; cf. the following footnote. Wittkower associates the motif of the gable with the Chigi Monti with the façade of Santa Maria del Popolo; and it appears in the two nearly contemporary façades by Fontana but, as Hager (fn. 23, below) rightly observed, it is not an unusual thing. 


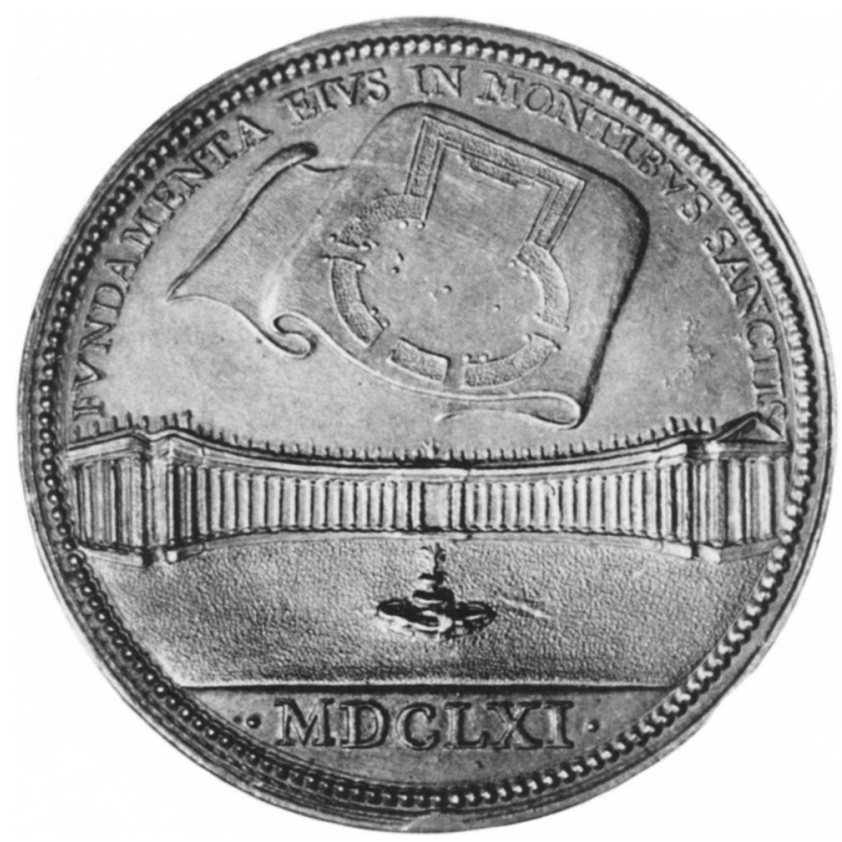

Fig. 14. Commemorative medal for the Square of Saint Peter's, I66I (photo: Fototeca Unione).

have been left out; they are clearly secondary in the system of articulation, which is the primary concern of the elevation drawing. Bonacina himself, in fact, indicated them at the termination of the colonnade but left them out, inconsistently, at the central cross-passage in his engraved elevation (Fig. 6), even though in his preparatory drawing (Fig. Io) he showed them all. In short, while the omission of the webs may signify that the workshop drawing in question preceded the Bonacina engraving and the Vatican Plan, it does not automatically exclude the possibility of a later date for the drawing. What we see here may well be a variant design produced only after the construction reached the entablature. The design above the entablature was still unsettled in I66I; the commemorative medal of that year (Fig. I4), in fact, shows a diminutive coat of arms, not at all like the one we see on the Bonacina engraving, above each crosspassage. $^{21}$

The drawing could, in other words, date from 1659 and any time thereafter up to 1667 when the construction was discontinued by the death of Pope Alexander VII. If we accept Fontana's authorship, with a full trust in Wittkower's

2I. Wittkower considered Bernini's final solution, as known in the Bonacina engraving, a derivative of the "Fontana" design: "Aber der Gedanke, in Analogie zur Fassade von S. Maria del Popolo über die Spitze des Dreieckgiebels die Chigi-Monti zu türmen, wird kaum Bernini selbst angehören, sondern scheint eher ein selbständiger Versuch des jugendlichen Carlo Fontana, die Stirnseiten der Kolonnaden zu monumentalisieren, nachdem sich Bernini zu ihrer Akzentuierung entschlossen hatte" (Brauer and Wittkower, Die Zeichnungen, p. 82). connoisseurship, we still have too much evidence against dating it before 1659 . There is indeed no reason why it could not be an alternative proposal submitted at some late stage of planning. Fontana may have been exceptionally precocious; but he was in 1659 a youth only twenty-one years of age rather than, as long believed, twenty-five-a fact brought to light by Donati in 1942 and missed by Wittkower still in $1958 .{ }^{22}$ It is also significant that the young architect's first independent works, the façades of SS. Faustino e Giovita and of San Biagio in Campitelli (Santa Rita), postdate the Bonacina engraving; the latter church, once dated 1660 by some, is now known to have been started only in $1665 .{ }^{23}$

Our two Windsor sketches are undistinguished as architectural drawings. But scrutiny, tedious as it may be, brought forth an abundance of data regarding Fontana's apprenticeship in Bernini's workshop. It also raises some questions.

There are Carlo Fontana's signed drawings related to Bernini's other architectural projects from the decade I660I670, but all several years after the piazza design, notably the complex of the church, palace, and piazza at Ariccia and the design of Palazzo Chigi-Odescalchi in Rome. ${ }^{24}$ There exist, in addition, even earlier drawings, also signed by Fontana, connected with Pietro da Cortona's work at Santa Maria della Pace, dated 1656-1657 and therefore from the years when Carlo was only eighteen to nineteen. ${ }^{25}$ All these drawings require a good fresh look in the light of our conclusions.

Not all architectural drawings are preliminary to a building project. Some may be merely descriptive rather than generative or prescriptive; that is to say, instead of tracing out the artist's process of working out a design or else presenting the appearance, finished or tentative, of the projected building, a drawing may be a record of an existing building and it may be archival in function, preliminary to a publication (as in our examples), or preparatory to con-

22. U. Donati, Artisti ticinesi, pp. 263-264, and R. Wittkower, Art and Architecture in Italy, I600-1750 (Baltimore, I958), p. 244; the date was corrected in Wittkower, 2nd ed., 1965.

23. H. Hager, "Le facciate dei SS. Faustino e Giovita e di S. Biagio in Campitelli (S. Rita) a Roma: a proposito di due opere giovanili di Carlo Fontana," Commentari, XXIII (1972), 262-271.

24. Bernini's project for the façade of Palazzo Chigi dates from early 1665 ; Brauer and Wittkower, Die Zeichnungen, p. 128. The Ariccia project is dated I662-1664; but among the voluminous documents connected with the project those with Fontana's signature which demonstrate his capacity as Bernini's clerk of works date only from I666; see G. Incisa della Rochetta, "Notizie sulla Fabbrica della Chiesa Collegiata di Ariccia," Rivista del Reale Istituto d'archeologia e storia dell'arte, I (I929), 349-392, esp. p. 37I. In addition, we have Fontana's own testimony of his participation in the design of the Scala Regia (Templum Vaticanum, pp. 235-239), which dates from $1663-1665$.

25. Bibl. Vat., Chig. P VII 9, fols. 68, 74, 75, and $77 / 78-$ mostly concerning the interior of the church. 
structional additions or modifications. One wonders, for example, if any of those signed drawings should necessarily be taken as evidence of Fontana's participation in the project just because it carries his signature. One wonders in what capacity Fontana worked for Pietro da Cortona (if he really did) and for Bernini at Ariccia. One wonders, above all, what exactly is the relationship between the façade of Palazzo Chigi-Odescalchi on a Vatican drawing, the design of which we know to be Bernini's, and the signature below it, which reads "Disegno Carlo Fontana."

TA B L E

BERNINI'S COLONNADE:

COLUMN DIAMETERS AND INTERCOLUMNIATIONS

one palmo $=0.2232 \mathrm{~m} .=0.732 \mathrm{Ift}$.

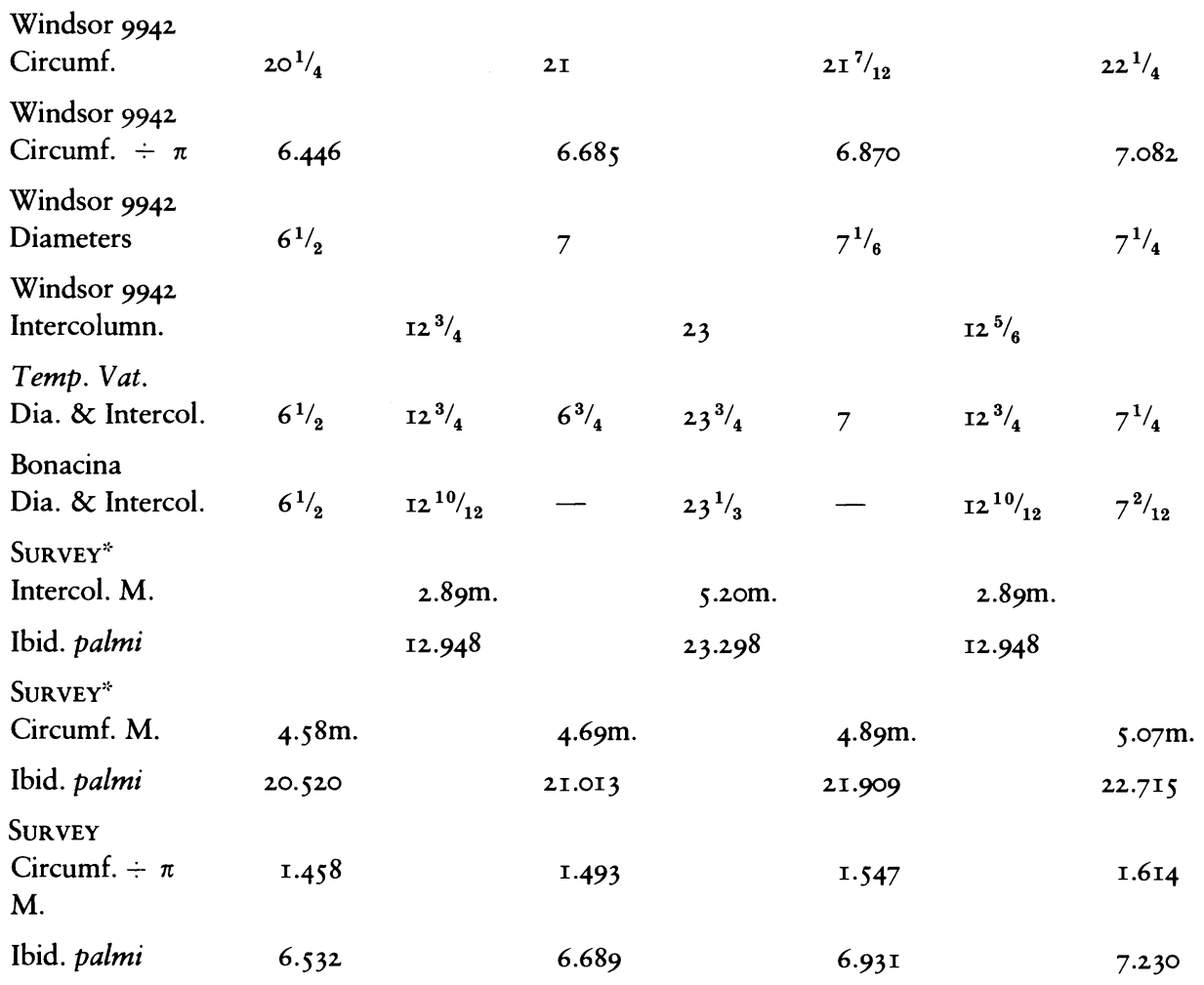

* Tape measurements by Ted Musho, February I96I, at my request. 